\title{
EKONOMI INDONESIA DAN PERMASALAHANNYA
}

Samuel Banurea

\author{
STIE Madani Balikpapan
}

Email: samuelbanurea@gmail.com

\begin{abstract}
Abstrak
Jurnal ini berangkat dari suatu kerangka teori, gagasan para ahli, ataupun pemahaman penulis berdasarkan pengalamannya, kemudian dikembangkan menjadi permasalahan - permasalahan beserta pemecahan - pemecahannnya yang diajukan untuk memperoleh pembenaran (verivikasi) dalam bentuk dukungan data emperis di lapangan. Pemerintah adalah ibarat seorang nahkoda yang sedan menjalankan sebuah kapal. Di dalam jangka pendek ia harus dapat menjaga kondisi kapalnya akan terhindar dari berbagai ancaman selama perjalanan. Sedangkan di dalam jangka panjang, nahkoda tersebut harus berusaha agar kapalnya dapat mencapai tujuan yang diinginkan / dicita-citakan. Tentu saja dalam kenyataannya perjalanan kapal yang dinahkodainya tidah semulus yang direncanakan, banyak sekali rintangan dan masalah yang selalu mengintai dan harus siap dipecahkan begitu muncul menghadangnya.

Penelitian ini bertujuan untuk mengetahui perkembangan Ekonomi Indonesia Dan Permasalahannya yang timbul didalamnya dimana Hasil penelitian ini menunjukkan Permasalahan utama dalam perekonomian yang selalu dihadapi oleh setiap negara. permasalahan tersebut adalah sebagai berikut: (1) Masalah pertumbuhan ekonomi (2) Masalah ketidakstabilan ekonomi (3) Masalah pengangguran (4) Masalah Kenaikan Harga-harga (Inflasi) (5) Masalah Neraca Perdagangan dan Neraca Pembayaran.
\end{abstract}

Kata kunci : Ekonomi Indonesia Dan Permasalahannya.

\section{PENDAHULUAN}

Ekonomi merupakan salah satu ilmu sosial yang mempelajari aktivitas manusia yang berhubungan dengan produksi, distribusi dan konsumsi terhadap barang dan jasa. Istilah "ekonomi”" sendiri berasal dari bahasa Yunani, yaitu (Oicos) yang berarti "keluarga, rumah tangga" dan (nomos) yang berarti "peraturan,hukum". Secara garis besar ekonom diartikan sebagai "aturan rumah tangga" atau "manajemen rumah tangga". Sementara yang dimaksud dengan ahli ekonomi atau ekonom adalah orang yang menggunakan konsep ekonomi dalam bekerja. 
Ilmu ekonomi sering dibedakan menjadi mikro dan makro ekonomi. Mikro ekonomi adalah bagian dari ilmu ekonomi yang berkenaan dengan kegiatan-kegiatan ekonomi dari unit-unit individual, sebagai bagian kecil dari keseluruhan kegiatan ekonomi. Ekonomi Makro adalah bagian dari ilmu ekonomi yang mempelajari masalah ekonomi secara keseluruhan (totalitet/aggregatif). Maksud digunakannya istilah aggegatif adalah untuk menekankan bahwa yang menjadi variabel-variabel total, seperti : pendapatan total (nasional/masyarakat/seluruh), tabungan masyarakat, investasi total, dan bukannya penganalisaan terperinci atas komponen-komponen yang bersifat total itu. Alat utama ekonomi makro adalah pendapatan nasional dan analisa pendapatan nasional. Analisa pendapatan nasional berguna untuk mengukur secara statistik tentang besarnya pendapatan nasional. Makalah ini akan membahas mengenai masalah utama dalam perekonomian, tujuan dan bentuk-bentuk kebijakan makro ekonomi.

Dua tahun berturut-turut, ekonomi dunia terus mengalami perlambatan. Perekonomian dunia dilanda berbagai macam gejolak ekonomi seperti perang dagang Amerika Serikat dan Tiongkok, perang geopolitik, dan perlambatan ekonomi di berbagai negara, dan gejolak ekonomi lainnya. Di tahun 2019, perlambatan ekonomi dunia masih terjadi, menurut IMF (2020), perekonomian dunia pada tahun 2019 tumbuh sebesar 2,9 persen atau mengalami pertumbuhan yang melambat dibandingkan dua tahun sebelumnya yaitu 3,9 persen pada tahun 2017 dan 3,6 persen pada tahun 2018. Nilai pertumbuhan ekonomi dunia tahun 2019 ini juga dibawah prediksi IMF pada April 2019 yang menyatakan bahwa ekonomi dunia tumbuh sebesar 3,3 persen.

Adanya pergeseran struktural pada perekonomian global turut andil dalam menyebabkan belum kuatnya perekonomian dunia. Banyak negara yang memberlakukan kebijakan yang berorientasi pada domestik, meningkatnya volatilitas arus modal dunia, semakin pesatnya perkembangan ekonomi digital, perubahan perilaku kegiatan ekonomi terkait respon perkembangan digital dalam ekonomi, serta terintegrasinya berbagai kebijakan yang menyatu, merupakan bentuk pergeseran struktural yang terjadi.

Terjadinya perlambatan ekonomi dunia terindikasi dari melambatnya pertumbuhan ekonomi di beberapa negara maju. Pada kelompok negara-negara maju terjadi 
perlambatan hingga 0,5 persen poin dalam kurun waktu 2018-2019 yaitu dari 2,2 persen di tahun 2018 menjadi 1,7 persen di tahun 2019. Amerika Serikat yang masuk ke dalam kelompok negara maju, di tahun 2018 mencatat pertumbuhan ekonomi sebesar 2,9 persen, turun menjadi 2,3 persen di tahun 2019. Turunnya investasi pada pabrik-pabrik peralatan baru serta terjadinya perlambatan pengiriman barang-barang dari pabrik ke toko selama kuartal ke-3 dan ke-4 tahun 2019, adalah faktor-faktor yang diduga melemahkan pertumbuhan ekonomi Amerika Serikat. Pada tahun 2018, kebijakan pemotongan pajak dan kenaikan belanja pemerintah yang cukup besar berdampak pada boostingperekonomian Amerika Serikat. Namun, di tahun 2019 yang mendorong masih positifnya kinerja ekonomi Amerika Serikat adalah masih kuatnya belanja konsumsi dan perbaikan defisit perdagangan di kuartal ke-4.

\section{Tabel 1}

Pertumbuhan Ekonomi Dunia, Negara Maju, Negara Berkembang, dan ASEAN (persen) Tahun 2015 - 2019

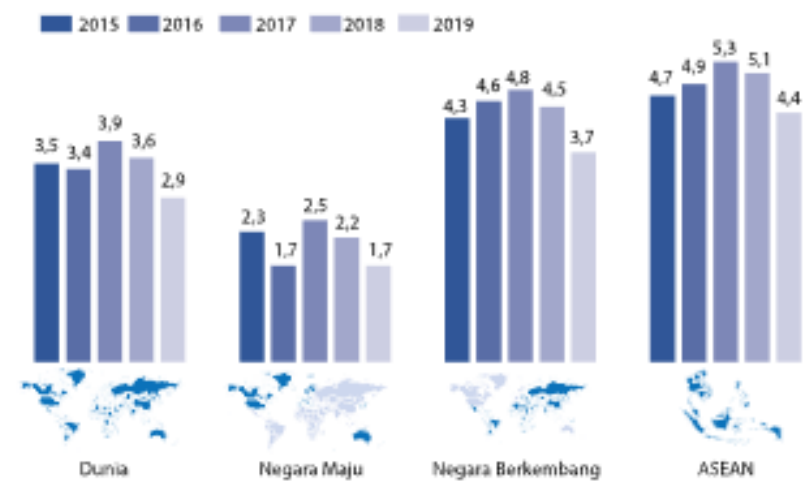

Sumber : IMF dan ADB (2020)

Pertumbuhan ekonomi di Kawasan Eropa juga melambat dari 1,9 persen pada tahun 2018 menjadi 1,2 persen pada tahun 2019. Melambatnya kinerja sektor industri akibat dari rendahnya permintaan global dan tersendatnya pertumbuhan konsumsi swasta akibat penurunan penjualan ritel di akhir tahun adalah faktor yang menyebabkan perlambatan ekonomi di Eropa. Beberapa negara seperti Perancis, Italia, Jerman, Spanyol, dan Belanda mengalami pelemahan permintaan domestik. Sementara itu, ekonomi Jepang pada tahun 2019 menunjukkan adanya peningkatan pertumbuhan yaitu dari 0,3 persen pada tahun 2018 menjadi 0,7 persen pada tahun 2019. Menguatnya permintaan domestik di awal tahun telah 
mengindikasikan adanya perbaikan kinerja ekonomi Jepang. Namun demikian, Jepang tetap mewaspadai hambatan ekonomi yang dapat memperlambat ekonomi seperti masih berlangsungnya sengketa perdagangan, melambatnya permintaan global, kenaikan pajak penjualan dan adanya bencana alam Topan Hagibis. Berbagai macam kebijakan yang dilakukan pemerintah Jepang dapat mempertahankan tingkat pertumbuhan ekonomi yang tetap positif sepanjang tahun 2019.

Sementara itu, pertumbuhan ekonomi di negara berkembang lebih tinggi dibandingkan pertumbuhan ekonomi negara maju. Pertumbuhan ekonomi negara berkembang rata-rata di tahun 2017 mencapai 4,8 persen, namun melambat hingga di tahun 2019 tercatat sebesar 3,7 persen. Kawasan Sub-Sahara Afrika mencatatkan perlambatan ekonomi sebesar 0,2 persen poin (menjadi 3,1 persen), Kawasan Asia melambat 0,8 persen poin (menjadi 5,5 persen), Kawasan Amerika Latin dan Karibia melambat 1 persen poin (menjadi 0,1 persen), Kawasan Timur Tengah dan Asia Tengah melambat 0,6 persen poin (menjadi 1,2 persen), serta Kawasan Eropa melambat 1,1 persen poin (menjadi 2,1 persen). Dari sekian kawasan negara berkembang, Kawasan Asia masih menjadi kawasan dengan pencapaian pertumbuhan ekonomi yang cukup tinggi karena didukung masih tingginya pertumbuhan ekonomi di Tiongkok dan India.

Tahun 2020 tinggal menghitung hari. Tentunya, di sepanjang 2020, ada banyak permasalahan yang ditemui dalam perekonomian Indonesia. Masalah-masalah ini yang menyebabkan pertumbuhan ekonomi Indonesia tak mencapai target pemerintah dalam APBN yang sebesar 5,3\%.Kementerian Keuangan meramal, ekonomi Indonesia hanya akan tumbuh sebesar 5,05\%. Wakil Menteri Keuangan Suahasil Nazara mengatakan, proyeksi tersebut sejalan dengan ekspektasi pertumbuhan ekonomi global yang kian menurun. Ekonomi dunia tahun ini diramal hanya akan tumbuh 3\%, level terendah sejak krisis finansial global pada 2008 silam dan jauh di bawah proyeksi awalnya yang sebesar 3,7\%.

Masalah Ekonomi adalah masalah yang sering terjadi dalam kehidupan sehari hari baik masalah dalam jual beli, tawar menawar ataupun ekspor impor. Dalam kehidupan sekarang terutama di Indonesia terdapat banyak masalah ekonomi yang terjadi diantaranya Pengangguran, Kemiskinan, Harga, Profit, Inflasi, Hutang, Sistem Ekonomi, Ekonomi politik, 
Kesejahteraan dan Pertumbuhan Ekonomi. Inti dari masalah ekonomi adalah adanya ketidakseimbangan antara kebutuhan manusia yang tidak terbatas dengan alat pemuas kebutuhan yang terbatas.

Pemerintah ibarat Seperti sebuah perusahaan yang sedang menjalankan kegiatan operasionalnya. Di dalam jangka pendek ia harus dapat menjaga kondisi penjualannya tetap stabil dan semakin membaik sehingga akan terhindar dari berbagai ancaman kebangkrutan. Sedangkan di dalam jangka panjang, pemimpin harus berusaha agar perusahaan dapat mencapai visi, misi dan tujuan yang diinginkan / dicita-citakan. Tentu saja dalam kenyataannya perjalanan perusahaan beroperasional tidak semulus yang direncanakan, banyak sekali rintangan dan masalah yang selalu dihadapi dan harus siap dipecahkan begitu muncul.

Di dalam rencana jangka panjang pemerintah harus menghantarkan masyarakat indonesia kepada sebuah kemakmuran, kesejahteraan lahir dan batin serta harus menghadapi masalah jangka panjang seperti masalah pertumbuhan ekonomi. Sedangkan di dalam jangka pendek pemerintah dituntut untuk selalu dapat membantu menciptakan iklim usaha yang kondusif / mendukung semua pihak. Sedangkan dipihak lain masih harus menghadapi masalah-masalah ekonomi jangka pendek. Dan sesungguhnya keberhasilan pemerintah dalam jangka panjang tidak terlepas dari kemampuannya menangani masalah-masalah ekonomi jangka pendek tersebut. Oleh sebab itulah pada artikel ini akan menjelaskan dan memberikan gambaran tentang jenis dan contoh permasalahan ekonomi makro di Indonesia dewasa ini.

\section{Tujuan Jurnal}

1. Mengetahui Pengertian Ekonomi

2. Mengetahui Perbedaan Makro Ekonomi dan Mikro Ekonomi

3. Mengetahui Masalah utama dalam perekonomian Indonesia

4. Mengetahui Kebijakan Makro Ekonomi

5. Mengetahui Betuk-bentuk Kebijakan Makro Ekonomi 


\section{PEMBAHASAN}

\section{Pengertian Ekonomi}

Ekonomi dalam banyak literatur ekonomi disebutkan berasal dari bahasa Yunani yaitu kata Oikos atau Oiku dan Nomos yang berarti peraturan rumah tangga. Dengan kata lain pengertian ekonomi adalah semua yang menyangkut hal-hal yang berhubungan dengan peri kehidupan dalam rumah tangga tentu saja yang dimaksud dan dalam perkembangannya kata rumah tangga bukan hanya sekedar merujuk pada satu keluarga yang terdiri dari suami, isteri dan anak-anaknya, melainkan juga rumah tangga yang lebih luas yaitu rumah tangga bangsa, negara dan dunia.

Secara umum, bisa dibilang bahwa ekonomi adalah sebuah bidang kajian tentang pengurusan sumber daya material individu, masyarakat, dan negara untuk meningkatkan kesejahteraan hidup manusia. Karena ekonomi merupakan ilmu tentang prilaku dan tindakan manusia untuk memenuhi kebutuhan hidupnya yang bervariasi dan berkembang dengan sumber daya yang ada melalui pilihan-pilihan kegiatan produksi, konsumsi dan atau distribusi. Berikut ini adalah pengertian dan definisi ekonomi menurut beberapa ahli;

a. Adam Smith

Ekonomi ialah penyelidikan tentang keadaan dan sebab adanyakekayaan negara.

b. Mill J.S

Ekonomi ialah sains praktikal tentang pengeluaran danpenagihan.

c. Abraham Maslow

d. Ekonomi adalah salah satu bidang pengkajian yang mencoba menyelesaikan masalah keperluan asas kehidupan manusia melalui penggemblengan segala sumber ekonomi yang ada dengan berasaskan prinsip serta teori tertentu dalam suatu sistem ekonomi yang dianggap efektif dan efisien.

e. Hermawan Kartajaya

Ekonomi adalah platform dimana sektor industri melekat diatasnya.

f. Paul A. Samuelson 
Ekonomi merupakan cara-cara yang dilakukan oleh manusia dan kelompoknya untuk memanfaatkan sumber-sumber yang terbatas untuk memperoleh berbagai komoditi dan mendistribusikannya untuk dikonsumsi oleh masyarakat.

\section{Pengertian dan Perbedaan Mikro Ekonomi dan Makro Ekonomi}

Ilmu ekonomi pada dasarnya adalah studi yang mempelajari tentang pemenuhan kebutuhan manusia terkait dengan kelangkaan sumber daya yang dimilikinya. Kelangkaan muncul sebagai akibat adanya kesenjangan antara kebutuhan dan keinginan manusiayang tidak terbatas dengan sumber yang terbatas.dalam pembahasan tentang ilmu ekonomi secara garis besar terbagi atas mikroekonomi dan makroekonomi.

Mikroekonomi adalah studi tentang bagaimana rumah tangga dan perusahaan mengambil keputusan dan bagaimana para pengambil keputusan ini berinteraksi di pasar. Prinsip utama mikroekonomi adalah bahwa rumah tangga dan perusahaan berusaha mencapai optimalisasi. Mikroekonomi menangani perilaku satuan-satuan ekonomi individual termasuk didalamanya dalam pengambilan keputusan dalam rangka untuk mengatasi permasalahan alokasi akibat kelangkaan sumber daya. Satan-satuan ini mencangkup konsumen, pekerja atau buruh, para penanam modal, pemilik tanah, perusahaan bisnis. intinya setiap individu atau entitas memainkan peranan dalam berfungsinya suatu perekonomian. Mikroekonomi menjelaskan cara dan alasan-alasan satuan ini membuat keputusan-keputusan ekonomis. biidang lain yang penting dari mikroekonomi adalah bagaimana satuan-satuan berinteraksi untuk membentuk satuan-satuan yang lebih besar, pasar dan industri.

Sementara makroekonomi, cabang utama dari ekonomi menangani kepada isu-isu yang bersifat makro atau lebih luas lagi, termasuk didalamnya mengenai jumlah agregat ekonomi, seperti tingkat dan laju pertumbuhan produksi nasional, suku bunga, pengangguran dan inflasi. Tetapi pembatasan antara makroekonomi dan mikroekonomi sudah semakin pudar belakangan ini.

Perbedaan mendasar dan utama antara mikroekonomi dan makroekonomi ada dua hal:

1. Dalam ekonomimikro uang tidak penting (money doesn't matter) yang penting adalah relative price (karen berpengaruh terhadap tingkat kemiringan) dan teori utility inilah 
yang menjadi jantung ekonomi mikro. Sementara dalam ekonomi makro uang (nominal price menjadi penting), karen yang terpenting adalah daya beli uang. Sehingga uang mampu diterjemakan menjadi permintaan (demand). Karena yang inilah berkembangmenjadi ilmu ekonomi moneter yang mempelajari cara mengatur jumlah uang beredar. Daya beli itu memilik implikasi dua hal yaitu: (1) daya beli domestik yang diukur dengan inflasi (kenaikan harga secara umum). (2) daya beli secara internasional yang diukur dengan kurs (nilai tukar uang).

2. Dalam ekonomi mikro berbicara mengenai individu dan perjumlahan individu. Sementara dalam ekonomi makro adanya unsur pemerintah dalam perekonomian. Ada tiga hal yang terkait dengan pemerintah: (1) pemerintah bertindak sebaagi pembeli besar, (2) pemerintah bertindak sebagai penjual besar, (3) pemerintah bertindak sebagai regulator. Dua unsur utama bermuara pada pembicaraan mengenai anggaran pemerintah (RAPBN), dan inilah memunculkan cabang ekonomi fiscal atau kadang dikenal pula dengan keuangan publik. Fungsi pemerintah sebagai regulator ini di tahun 1980-an berkembang ilmu ekonomi baru yaitu ekonomi kebijakan.

Sehingga mikroekonomi menitikberatkan kepada analisis mengenai masalah membuat pilihan untuk:

a. Mewujudkan efesiensi dalam penggunaan berbbagai sumber daya, karena keseimbangan dalam perekonomian dapat tercapai jika efesiensi dalam penggunaan sumber daya.

b. Mencapai kepuasan atau kegunaan maksimum baik dari sisi konsumen maupun dari sisi produsen atas keseimbangan pasar yang terjadi.

Sementara analisis makroekonomi menitik beratkan tingkat kegiatan atau menerangkan mengenai:

1) Bagaimana segi permintaan dan penawaran menentukan tingkat kegiatan dalam perekonomia.

2) Masalah-masalah utama yang selalu di hadapi setiap perekonomian. 
3) Peranan kebijakan dan campur tangan pemerintah untuk mengatasi masalah ekonomi yang dihadapi untuk mewujudkan prestasi kegiatan ekonomi di tingkat yang dikehendakin.

Kemudian perbedaan esensiel antara ilmu makroekonomi konvensional. Perbedaan utama adalah terkait dengan uang. Dalam ekonomi konvensional. Pandangan mengenai uang terdiri dua mazhab besar, yaitu:

a. Uang adalah flow concept (teori irving fisher). Menurut irving fisher uang harus selalu diputar dalam perekonomian. Agar dapat memacu pertumbuhan ekonomi suatu negara. Model irving fisher dapat ditulis sebagai berikut:

$$
\mathrm{MV}=\mathrm{PT}
$$

Di mana :

$\mathrm{M}$ adalah besaran uang

$\mathrm{V}$ adalah kecepatan putaran uang

$\mathrm{P}$ adalah tingkat harga

T adalah jumlah transaksi yang dilakukan

Dengan model irving fisher di atas mengemukakan bahwa semakin cepat perputaran uang maka akan semikin tinggi pula pendapatan nasional yang di hasilkan oleh suatu negara. Peningkatan pendapatan nasional menjadi indikator pertumbuhan ekonomi suatu negara persamaan Ptdalam model di atas inilah yang dikenal sebagai pendapatan nasional.

b. Pandangan konvensional tentang uang berikutnya adalah yang sebagai stock concept yang di kembangkan oleh alfred marshali, dengan pesamaan

$$
\begin{aligned}
& M=k . P T \\
& M=I / V . P T
\end{aligned}
$$

Dimana dalam konsep alfred marshali uang di anggap sebagai barang modal, karena uang di asumsikan sebagai barang modal maka uang boleh ditumpuk menjadi kekayaan. Jumlah uang beredar adalah jumlah promosi tertentu uang yang ingin di pegang. 


\section{Masalah Utama Dalam Perekonomian Indonesia}

Permasalahan utama dalam perekonomian Indonesia, dan harus mampu dipecahkan secara baik oleh setiap pemerintah Indonesia agar kesejahteraan dan kemakmuran masyarakat dapat tercapai, adapun permasalahan tersebut adalah sebagai berikut:

\section{Masalah Pertumbuhan Ekonomi}

Tahun 2019 menjadi tahun yang penuh tantangan dimana perekonomian global mengalami pertumbuhan terendah dalam 10 tahun terakhir, dimana hanya mampu tumbuh 2,3 persen pada 2019. Pertumbuhan yang melambat ini terjadi karena melemahnya aktivitas perdagangan dan manufaktur dunia, akibat terjadinya perselisihan perdagangan yang berkepanjangan, antara 2 negara adidaya Amerika Serikat dan Tiongkok. Selain itu pertumbuhan yang melambat juga disebabkan oleh gejolak keuangan atau peningkatan ketegangan geopolitik.

Pada saat yang sama, digitalisasi ekonomi dan keuangan semakin marak, dengan segala manfaat dan risikonya. Perekonomian global yang melambat telah mendorong ketidakpastian di pasar keuangan dunia tetap tinggi dan memengaruhi pola arus modal global. Secara keseluruhan, berbagai dinamika ini berdampak pada melambatnya arus modal asing ke negara berkembang dan memberikan tekanan kepada banyak mata uang negara berkembang. Namun di tengah ekonomi global yang menurun, pertumbuhan ekonomi Indonesia pada 2019 tetap mampu tumbuh dikisaran angka 5 persen lebih. Keberhasilan ini merupakan hasil dari sinergi kebijakan yang ditempuh Pemerintah, Bank Indonesia dan otoritas terkait. Kebijakan makroprudensial yang akomodatif ditempuh untuk mendorong kredit sebagai sumber pembiayaan.

Dalam implementasinya, sinergi kebijakan ditujukan untuk mendorong momentum pertumbuhan ekonomi, mempertahankan stabilitas perekonomian dan stabilitas sistem keuangan, serta memperkuat struktur perekonomian. Dalam kaitan ini, Pemerintah pada 2019 meningkatkan stimulus kebijakan fiskal guna mendorong pertumbuhan ekonomi, dengan tetap menjaga kesinambungan fiskal. Kebijakan fiskal diimplementasikan melalui tiga strategi utama, yaitu memobilisasi pendapatan dengan tetap mendukung penguatan iklim investasi, meningkatkan kualitas belanja agar lebih 
efektif dan produktif untuk mendukung program prioritas, serta mendorong efisiensi dan inovasi pembiayaan (creative financing).

Tujuan Kebijakan Moneter adalah untuk mencapai dan memelihara kestabilan nilai rupiah. Tujuan ini sebagaimana tercantum dalam UU No. 23 Tahun 1999 tentang Bank Indonesia, yang sebagaimana diubah melalui UU No. 3 Tahun 2004 dan UU No. 6 Tahun 2009 pada pasal 7. Kestabilan rupiah yang dimaksud mempunyai dua dimensi. Dimensi pertama kestabilan nilai rupiah adalah kestabilan terhadap harga-harga barang dan jasa yang tercermin dari perkembangan laju inflasi. Sementara itu, dimensi kedua terkait dengan perkembangan nilai tukar rupiah terhadap mata uang negara lain.

Dalam upaya mencapai tujuan rersebut, Bank Indonesia sejak 1 Juli 2005 menerapkan kerangka kebijakan moneter Inflation Targeting Framework (ITF). Kerangka kebijakan tersebut dipandang sesuai dengan mandat dan aspek kelembagaan yang diamanatkan oleh Undang-Undang. Dalam kerangka ini, inflasi merupakan sasaran yang diutamakan (overriding objective). Bank Indonesia secara konsisten terus melakukan berbagai penyempurnaan kerangka kebijakan moneter, sesuai dengan perubahan dinamika dan tantangan perekonomian yang terjadi, guna memperkuat efektivitasnya.

Pada tahun 2019, sinergi yang ditempuh Pemerintah, Bank Indonesia, dan otoritas terkait mampu merespon dan mengarahkan kebijakan untuk mendorong perekonomian agar dapat kembali meningkat dan mampu menahan gejolak perekonomian dunia. Kebijakan yang diambil pemerintah mampu membuat perekonomian Indonesia tetap tumbuh, namun pertumbuhan kredit Indonesia terindikasi perlu terus didorong menuju kapasitas optimumnya. Dorongan tidak hanya untuk meningkatkan level pertumbuhan ekonomi, namun juga untuk memperpendek siklus perlambatan pertumbuhan sehingga dapat segera kembali menuju level optimum.

Pertumbuhan ekonomi dapat didefinisikan sebagai perkembangan kegiatan dalam perekonomian yang menyebabkan barang dan jasa yang diproduksikan dalam masyarakat bertambah. Masalah pertumbuhan ekonomi dapat dipandang sebagai masalah makroekonomi dalam jangka panjang. Dari satu periode ke periode lainya kemampuan 
suatu negara untuk menghasilkan barang dan jasa akan meningkat. Kemampuan yang meningkat disebabkan karena faktor-faktor produksi akan selalu mengalami pertambahan dalam jumlah dan kualitasnya. Investasi akan menambah jumlah barang modal, teknologi yang digunakan berkembang.

Gambar 2.1 berikut menunjukkan Pertumbuhan Ekonomi Indonesia di Triwulan II tahun 2020 yang diperoleh dari Badan Pusat Statisti.

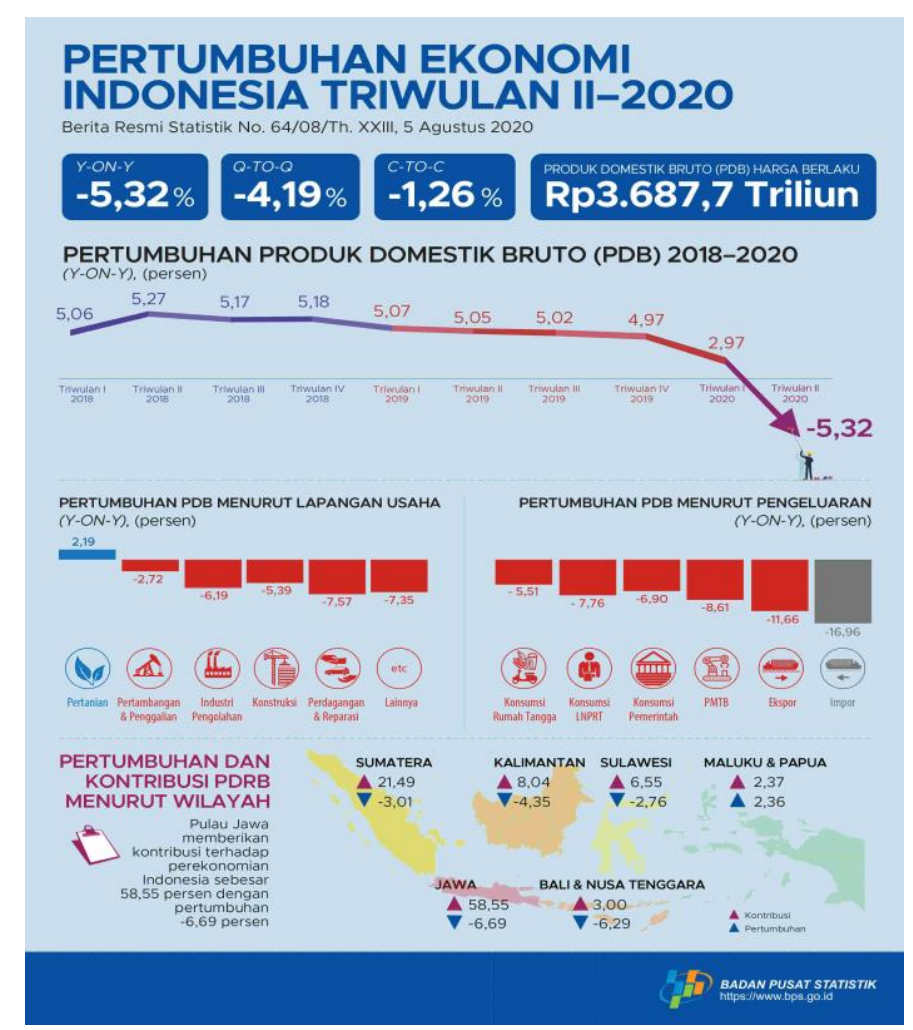

Gambar 1

Pertumbuhan Ekonomi Indonesia di Triwulan II tahun 2020

Sumber BPS 2020

Pada gambar 2.1 Menunjukkan PDB kita di kuartal II mengalami penurunan ke level $-5.32 \%$ dengan total PDB (berdasarkan Harga Berlaku) nya adalah 3.687,7 Triliun dimana sebelumnya Triwulan mengalami penurunan $2.97 \%$ dari sebelumnya triwulan IV tahun 2019 sebesar 4.97\%, penurunan ini akibat krisis kesehatan (virus Corona) yang terjadi di sepanjang tahun 2020 dan berdampak terhadap lesunya perekonomian banyak Negara Negara didunia termasuk Indonesia. Pada gambar juga menunjukkan hampur di semua pulau di Indonesia mengalami penurunan kecuali Pulau Papua mengalami pertumbuhan sebesar $2.36 \%$ dan pertumbuhan yang paling banyak adalah pulau jawa sebesar $-6.69 \%$ 
akibat banyak pabrik/ industry yang berhenti peroperasi karena pembeli berkurang kemudian penurunan ini diikuti Pulau Bali dan NTB sebesar -6,29\% akibat dari lesunya dunia parawisata dewasa ini.

Adapun Gambaran Umum tentang perekonomian Indonesia berdasarkan besaran Produk Domestik Bruto (PDB) atas dasar harga berlaku triwulan II-2020 mencapai Rp3.687,7 triliun dan atas dasar harga konstan 2010 mencapai Rp2.589,6 triliun. Ekonomi Indonesia triwulan II-2020 terhadap triwulan II-2019 mengalami kontraksi pertumbuhan sebesar 5,32 persen (year on year). Dari sisi produksi, Lapangan Usaha Transportasi dan Pergudangan mengalami kontraksi pertumbuhan tertinggi sebesar 30,84 persen. Dari sisi pengeluaran, Komponen Ekspor Barang dan Jasa serta Impor Barang dan Jasa mengalami kontraksi pertumbuhan masing-masing sebesar 11,66 persen dan 16,96 persen. Ekonomi Indonesia triwulan II-2020 terhadap triwulan sebelumnya mengalami kontraksi pertumbuhan sebesar 4,19 persen (quartal to quartal). Dari sisi produksi, Lapangan Usaha Transportasi dan Pergudangan mengalami kontraksi pertumbuhan tertinggi sebesar 29,22 persen. Sementara dari sisi pengeluaran, Komponen Ekspor Barang dan Jasa serta Impor Barang dan Jasa mengalami kontraksi pertumbuhan masing-masing sebesar 12,81 persen dan 14,16 persen. Ekonomi Indonesia semester I-2020 terhadap semester I-2019 mengalami kontraksi sebesar 1,26 persen (c-to-c). Dari sisi produksi, kontraksi pertumbuhan terbesar terjadi pada Lapangan Usaha Transportasi dan Pergudangan sebesar 15,07 persen. Sementara dari sisi pengeluaran semua komponen terkontraksi, dengan kontraksi tertinggi terjadi pada Komponen Pengeluaran Konsumsi Lembaga Nonprofit yang Melayani Rumah Tangga (PK-LNPRT) sebesar 6,44 persen. Struktur ekonomi Indonesia secara spasial pada triwulan II-2020 didominasi oleh kelompok provinsi di Pulau Jawa sebesar 58,55 persen, dengan kinerja ekonomi yang mengalami kontraksi pertumbuhan sebesar 6,69 persen. Sementara itu kelompok Pulau Maluku dan Papua mencapai pertumbuhan tertinggi sebesar 2,36 persen, walaupun kontribusinya terkecil (kurang dari tiga persen) dibanding kelompok pulau lainnya.

Perkembangan kemampuan produksi barang dan jasa sebagai akibat pertambahan faktor-fatktor produksi pada umumnya tidak selalu diikuti oleh pertambahan produksi 
barang dan jasa yang sama besarnya. Pertambahan potensi memproduksi kerapkali lebih besar dari pertambahan produksi yang sebenarnya. Dengan demikian pertambahan ekonomi adalah lebih lambat dari potensi. Tingkat kegiatan ekonomi dibawah ini menyebabkan sebagian faktor-faktor produksi menganggur termasuk tenaga kerja dan ini terutama di sebabkan oleh kekurangan pengeluaran agregat.

Kesenjangan dapat terjadi antara pertumbuhan ekonomi potensial dan pertumbuhan ekonomi sebenarnya. Pendapatan nasional potensional yaitu tingkat pendapatan nasional yang dicapai apabila tenaga kerja sepenuhnya digunakan. Garis pendapatan nasional potensial yang semakin naik tersebut menggambarkan bahwa faktor-faktor produksi yang semakin banyak jumlahnya dari tahun ke tahun dan kemajuan teknologi yang menaikan produtivitas menyebabkan semakin lama semakin banyak produksi nasional yang dapat di wujudkan. Akan tetapi perekonomian tidak selalu menggunakan semua faktor-faktor produksi yang tersedia, termasuk tenaga kerja yang tersedia. Kekurangan pengeluaran agregad yang menyebabkan sebagian tenaga kerja menganggur dan perekonomian tidak akan mewujudkan pendapatan nasional potensial.

\section{Masalah Pengangguran}

Pengangguran adalah suatu kedaan dimana orang yng tergolong dalam angkatan kerja ingin mendapatkan pekerjaan tetapi belum memperolehnya. Sebagai contoh, seorang ibu rumah tangga yang tidak ingin bekerja karen ingin mengurus keluarganya tidak tergolong sebagai pengangguran. Seorang anak keluarga kaya yang tidak mau bekerja karena gajinya lebih rendah dari uang suku yang yang bisa di dapattidak tergolong sebagai pengangguran. Ibu rumah tangga dan anak keluarga kaya tersebut dinamakan sebagai penganggran sukarela.

Faktor utama yang menimbulkan pengangguran dalah kekurangan pengeluaran agregat. Para pengusaha memproduksi barang dan jasa dengan maksut untuk mencari keuangan. Keuangan tersebut hanya akan dapat diperoleh apabila para pengusaha dapat menjual barang yang di produksi, kenaikan produksi akan menambah penggunaan tenaga kerja. Dengan demikian terdapat hubungan erat antara pendapatan nasional yang dicapai 
dengan penggunaan tenaga kerja yang dilakukan. Semakin tinggi pendapatan nasional, semakin banyak penggunaan tenaga kerja dalam perekonomian.

Salah satu faktor penting yang menentukan kemakmuran suatu masyarakat adalah tingkat pendapatan, pendaatan masyarakat mencapai maksimum apabila tingkat penggunaan tenaga kerja penuh dapat diwujudkan. Pengangguran mengurangi pendapatan masyarakat, ini berarti individu pengangguran menimbulkan berbagai masalah ekonomi dan sosial kepada yang mengalami. Ketidaan pendapatan menyebabkan para pengangguran harus mengurangi pengeluaran konsumsinya. Disamping itu, ia dapat memberikan efek psikologis yang kuarng baik kepadapenganggur dan keluarganya.

Apabila tingkat pengangguran disuatu negara sangat tinggi maka akan dapat mengakibatkan kekacauan politik dan sosial. Salah satu contoh adalah penjarahan besar-besaran yang terjadi di indonesia pada tahun 1998 merupakan akibat dari tingginya tingkat pengangguran akibat banyaknya pemutusan hubungan kerja (PHK) pada waktu tersebut.

Pengangguran atau tunakarya merupakan istilah untuk seseorang yang tidak melakukan pekerjaan sama sekali. Dengan kata lain, pengangguran merupakan, seseorang yang dalam angkatan kerja, yang sedang mencari pekerjaan namun belum mendapatkan pekerjaan. Pengangguran umumnya dikarenakan jumlah angkatan kerja tidak sebanding dengan jumlah lapangan kerja di suatu wilayah. Pengangguran seringkali menjadi masalah dan selalu ada di setiap pengertian negara berkembang.

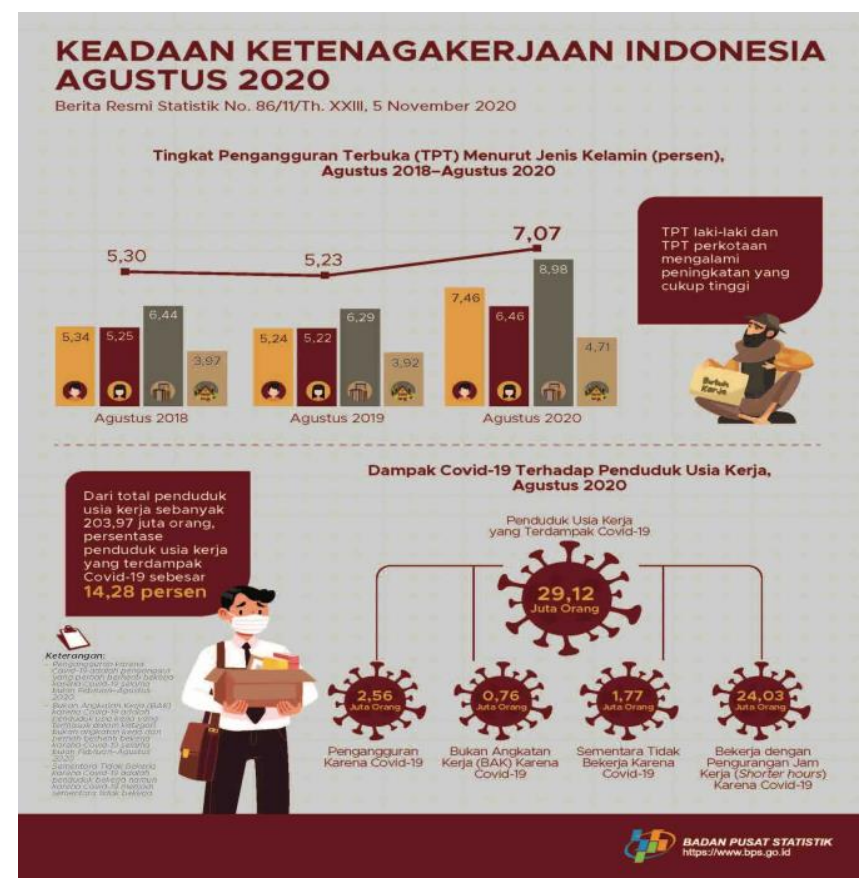


Pada Gambar 2 Menunjukkan Kondisi keadaan Kondisi ketenagakerjaan di Indonesia. Jumlah angkatan kerja pada Agustus 2020 sebanyak 138,22 juta orang, naik 2,36 juta orang dibanding Agustus 2019. Sejalan dengan kenaikan jumlah angkatan kerja, Tingkat Partisipasi Angkatan Kerja (TPAK) juga naik sebesar 0,24 persen poin. Tingkat pengangguran terbuka (TPT) Agustus 2020 sebesar 7,07 persen, meningkat 1,84 persen poin dibandingkan dengan Agustus 2019, hal ini menjadi masalah serius dari pemerintah untuk segera menurunkannya. Untuk penduduk yang bekerja saat ini sebanyak 128,45 juta orang, dan mengalami penueurnan sebanyak 0,31 juta orang dari Agustus 2019. Untuk penyediaan Lapangan pekerjaan yang mengalami peningkatan persentase terbesar adalah Sektor Pertanian (2,23 persen poin), hal ini disebabkan karena semakin banyaknya orang berpikir untuk melakukan kegiatan bertani dari pada hidup di kota dimanaterlihat dari sektor yang mengalami penurunan terbesar yaitu Sektor Industri Pengolahan (1,30 persen poin). Dewasa ini ada sSebanyak 77,68 juta orang $(60,47$ persen) bekerja pada kegiatan informal, naik 4,59 persen poin dibanding Agustus 2019 dan dalam setahun terakhir, persentase pekerja setengah penganggur dan persentase pekerja paruh waktu naik masing-masing sebesar 3,77 persen poin dan 3,42 persen poin.

Masalah serius Negara saat ini yaitu Terdapat 29,12 juta orang (14,28 persen) penduduk usia kerja yang terdampak Covid-19, terdiri dari pengangguran karena Covid-19 (2,56 juta orang), Bukan Angkatan Kerja (BAK) karena Covid-19 (0,76 juta orang), sementara tidak bekerja karena Covid-19 (1,77 juta orang), dan penduduk bekerja yang mengalami pengurangan jam kerja karena Covid-19 (24,03 juta orang). Beginilah Kondisi umum yang terjadi di Negara ini dan ini merupakan masalah serius yang harus dihadapi Negara dan bangsa untuk bisa terus berkambang dan maju.

\section{Masalah Kenaikan Harga-harga (Inflasi)}

Permasalahn inflasi adalah masalah ekonomi yang disebabkan karena kenaikan tingkat harga secara terus menerus dalam jangka waktu tertentu. Secara sederhananya, 
kenaikan harga ini naik dari bulan ke bula, atau dari tahun ke tahun. Karena adanya beban seperti ini, maka perekonomian tidak dapat mencapai tujuan stabilitasnya.

Inflasi dapat menyebabkan meningkatnya rata-rata harga produksi dan jasa. Ketika inflasi terjadi, harga dalam keadaan ini naik diatas rata-rata. Dan hanya beberapa saja yang naik dibawah rata-rata. Karena harga naik, maka tingkat produktivitas juga bisa meningkat bebannya, sehingga harga yang diproduksi juga meningkat. Ketika inflasi terjadi pada salah satu jenis, maka juga dapat mempengaruhi harga pada jenis lain.

Inflasi dapat didefinisikan sebagai suatu proses kenaikan harga-harga yang berlaku secara umum dan dalam waktu tertentu pada suatu perekonomian. Tingkat inflasi berbeda dari suatu periode ke periode lainnya dan berbeda pula dari satu negara ke negara lainnya. Tingkat inflasi adakalanya rendah yaitu hanya 2-3 persen, ada pula yang moderat 4-10 persen, atau bahkan ada yang sangat tinggi mencapai beberapa puluh atau beberapa ratus persen atau beberapa ribu persen dalam setahun (hyper inflation).

Masalah inflasi diakibatkan oleh banyak factor. Di Negara-negara industry pada umumnya inflasi bersumber dari salah satu atau gabungan dari dua masalah berikut: (1) Tingkat pengeluaran agregat yang melebihi kemampuan perusahaan-perusahaan untuk menghasilkan barang-barang dan jasa-jasa. Keinginan untuk mendapatkan barang akan mendorong konsumen meminta barang tersebut pada tingkat harga yang lebih tinggi (2) Pekerja-pekerja diberbagai Kegiatan ekonomi menuntut kenaikan upah. Apabila persediaan pekerja sangat sedikit, maka perusahaan akan bersedia menaikkan upah dengan konsekuensi terjadi peningkatan harga jual barang 


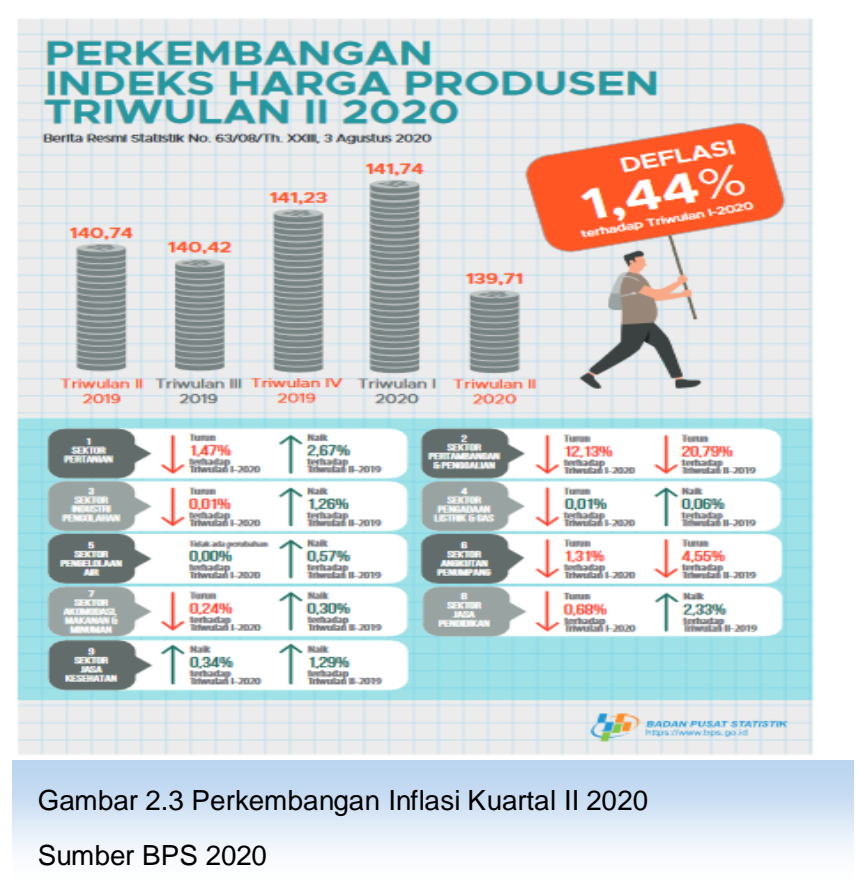

Gambaran Umum Inflasi di Indonesia menurut Gambar 2.3 pada Triwulan II 2020 dapat digambarkan dimana Indeks Harga Produsen (IHP) gabungan tiga sektor (Sektor Pertanian, Pertambangan dan Penggalian, dan Industri Pengolahan) pada triwulan II-2020 turun 1,44 persen terhadap triwulan I-2020 (quartal to quartal) dan turun 0,73 persen terhadap triwulan II-2019 (year on year). Untuk IHP Sektor Pertanian triwulan II-2020 turun 1,47 persen terhadap triwulan I-2020 (quartal to quartal) dan naik 2,67 persen terhadap triwulan II-2019 (year on year). Perkembangan IHP Sektor Pertambangan dan Penggalian triwulan II-2020 turun 12,13 persen dibandingkan triwulan I-2020 (quartal to quartal) dan turun 20,79 persen terhadap triwulan II-2019 (year on year). IHP Sektor Industri Pengolahan triwulan II-2020 turun 0,01 persen terhadap triwulan I-2020 (quartal to quartal) dan naik 1,26 persen terhadap triwulan II-2019 (year on year). IHP Sektor Pengadaan Listrik dan Gas triwulan II-2020 turun 0,01 persen dibandingkan dengan triwulan I-2020 (quartal to quartal) dan terhadap triwulan II-2019 (year on year) naik 0,06 persen. IHP Sektor Pengelolaan Air triwulan II-2020 tidak mengalami perubahan jika dibandingkan dengan triwulan I-2020 (quartal to quartal) dan naik 0,57 persen terhadap triwulan II-2019 (year on year). IHP Sektor Angkutan Penumpang triwulan II-2020 turun 1,31 persen terhadap triwulan I-2020 (quartal to quartal) dan terhadap triwulan II-2019 (year on year) turun 4,55 
persen. IHP Sektor Penyediaan Akomodasi dan Makanan Minuman triwulan II-2020 turun 0,24 persen terhadap triwulan I-2020 (quartal to quartal) dan naik 0,30 persen terhadap triwulan II-2020 (year on year). IHP Sektor Jasa Pendidikan triwulan II-2020 turun 0,68 persen terhadap triwulan I-2020 (quartal to quartal) sedangkan terhadap triwulan II-2019 (year on year) naik 2,33 persen. IHP Sektor Jasa Kesehatan triwulan II-2020 naik 0,34 persen terhadap triwulan I-2020 (quartal to quartal) dan naik 1,29 persen terhadap triwulan II-2020 (year on year). di kuartal II ini yang mengalami penurunan yang sangat drastic masih di sector pertambangan dan transportasi dimana banyak pesawat pesawat yang tidak bisa terbang akibat sepi penumpang.

DiIndonesia masalah inflasi ini erat kaitannya dengan tingkat penggunaan tenaga kerja. Selain itu inflasi dapat pula berlaku sebagai akibat dari (1) kenaikan harga-harga barang yang diimpor (2) penambahan penawaran uang yang berlebihan tanpa diikuti oleh penambahan produksi dan penawaran barang (3) kekacauan politik dan ekonomi sebagai akibat pemerintah yang kurang bertanggung jawab (4) Kondisi Lesunya daya beli akibat sebuah bencana (saat ini pandemic corona). Saat ini Inflasi yang terjadi di Indonesia berakibat buruk kepada individu, masyarakat dan aktivitas perekonomian secara umum. Salah satu dampak negative dari inflasi ialah akan menurunkan taraf kemakmuran sekelompok masyarakat terutama masyarakat berpenghasilan tetap. Prospek pembangunan ekonomi jangka panjang akan menjadi semakin memburuk jika inflasi tidak dapat dikendalikan.

\section{Masalah Neraca Perdagangan dan Neraca Pembayaran}

Kegiatan ekspor dan impor merupakan bagian yang penting dari Kegiatan perekonomian suatu Negara. Istilah perekonomian terbuka berarti suatu perekonomian itu mempunyai hubungan ekonomi dengan Negara-negara lain dan terutama ini dilakukan dengan menjalankan Kegiatan ekspor dan impor. Disamping itu, aliran modal untuk investasi juga berlaku diantara berbagai Negara. Sejak lama para ekonom klasik telah menunjukkan bahwa Kegiatan perdagangan luar negeri mempunyai sumbangan penting kepada tingkat pertumbuhan ekonomi suatu Negara. Dengan ekspor, perusahaan dalam negeri mampu mengembangkan kegiatannya. Kegiatan impor juga 
dapat member sumbangan kepada pertumbuhan ekonomi. Industri-industri dapat mengimpor mesin-mesin dan bahan mentah yang diperlukannya.

Neraca perdagangan Indonesia pada tahun 2019 mengalami defisit sebesar US $\$ 3,23$ miliar dengan total ekspor senilai US\$167,49 miliar dan total impor senilai US\$170,73 miliar. Defisit neraca perdagangan pada tahun tersebut masih lebih baik dibandingkan dengan tahun 2018 yang mengalami defisit hingga US\$ 8,69 miliar. Menurunnya defisit di tahun 2019 disebabkan oleh neraca perdagangan nonmigas Indonesia mengalami surplus sebesar US\$6,15 miliar, meskipun neraca perdagangan migas mengalami defisit sebesar US\$9,38 miliar. Sedangkan di tahun 2018 neraca perdagangan non migas hanya mampu mencapai surplus sebesar US\$3,99 miliar sementara defisit neraca perdagangan migas cukup dalam hingga US\$12,69 miliar. Neraca perdagangan nonmigas sangat berkontribusi pada perbaikan defisit neraca perdagangan di tahun 2019. Sementara itu tingginya impor migas paling berperan dalam defisit neraca perdagangan. Untuk mengurangi defisit neraca perdagangan migas, kebijakan pemerintah di tahun 2019 adalah program B-20 dan pembelian minyak mentah hasil produksi domestik oleh Pertamina. Program tersebut efektif dalam menekan impor migas (www.mediaindonesia.com).

Tabel 2

Neraca Perdagangan Indonesia (Juta US\$) Tahun 2017-Tw I 2020

\begin{tabular}{lrrrr} 
& 2017 & 2018 & 2019 & Tw/ 2020 \\
\hline Migas & $-8571,8$ & $-12697,2$ & $-9380,5$ & $-3066,7$ \\
Non Migas & 20414,5 & 3998,7 & 6150,1 & 5658,6 \\
jumlah & 11842,7 & $-8698,5$ & $-3230,4$ & 2591,9
\end{tabular}

Sumber : Indikator Ekonomi Mei 2020, BPS

Pada awal tahun 2020 di tengah ketidakpastian ekonomi global serta pandemi Covid-19, neraca perdagangan Indonesia justru memberikan sinyal positif. Pada triwulan I 2020, neraca perdagangan Indonesia surplus sebesar US\$2,59 miliar. Angka tersebut membaik dibandingkan kondisi triwulan I 2019 yang defisit US\$0,63 miliar. Surplus tersebut ditopang oleh baiknya kinerja ekspor nonmigas yang berpengaruh pada 
surplus neraca perdagangan nonmigas mencapai US\$5,66 miliar. Sementara itu neraca perdagangan migas mengalami defisit mencapai US $\$ 3,07$ miliar, diakibatkan oleh menurunnya nilai ekspor dibarengi dengan meningkatnya nilai impor di sektor tersebut. Peningkatan impor tersebut perlu diwaspadai mengingat kondisi yang sedang dihadapi Indonesia saat ini.

Namun perlu disadari bahwa keterbukaan suatu perekonomian tidak selalu menguntungkan. Impor yang berlebihan dapat mengurangi Kegiatan ekonomi dalam negeri karena hal tersebut akibat dari penggunaan barang luar negeri oleh konsumen dalam negeri, yang berimplikasi pada penurunan konsumsi pada barang dalam negeri. Apabila terjadi penurunan produksi barang dalam negeri, akan mengakibatkan pengurangan tenaga kerja. Dalam keadaan ini, modal dalam negeri akan mengalir ke luar negeri.

\section{Masalah Suku Bunga}

Suku bunga merupakan biaya yang dikenakan dari bank untuk memberi pinjaman. Perusahaan yang meminjam uang dari fungsi bank, dan ketika suku bunga meningkat, maka memberikan pengaruh pada bisnis nya secara langsung.

\section{Tabel 3}

Suku Bunga Kredit Rupiah Menurut Kelompok Bank 2019 dan 2020

\begin{tabular}{|c|c|c|c|c|c|c|c|c|c|c|c|c|c|}
\hline \multirow[b]{2}{*}{ Kelompok Bank } & \multicolumn{13}{|c|}{ Suku Bunga Kredit Rupiah Menurut Kelompok Bank } \\
\hline & Jan & Feb & Mar & Apr & May & Jun & Jul & Aug & Sep & Oct & Nov & Dec & Tahunan \\
\hline Bank Persero - Modal Kerja & 9.77 & 9.75 & 9.7 & 9.38 & 9.18 & 9.14 & 9.09 & 9.06 & - & - & - & - & 9.38 \\
\hline Bank Persero - Investasi & 9.7 & 9.66 & 9.57 & 9.26 & 9.12 & 9.12 & 9.08 & 9.06 & - & - & - & - & 9.32 \\
\hline Bank Persero - Konsumsi & 11.04 & 11.02 & 10.99 & 10.92 & 10.78 & 10.75 & 10.73 & 10.7 & - & - & - & - & 10.87 \\
\hline Bank Pemerintah Daerah - Modal Kerja & 10.76 & 10.77 & 10.75 & 10.75 & 10.64 & 10.58 & 10.55 & 10.54 & - & - & - & - & 10.67 \\
\hline Bank Pemerintah Daerah - Investasi & 11.02 & 10.98 & 10.9 & 10.87 & 10.73 & 10.66 & 10.62 & 10.57 & - & - & - & - & 10.79 \\
\hline Bank Pemerintah Daerah - Konsumsi & 11.73 & 11.72 & 11.69 & 11.67 & 11.72 & 11.69 & 11.68 & 11.66 & - & - & - & - & 11.70 \\
\hline Bank Swasta Nasional - Modal Kerja & 10.59 & 10.48 & 10.36 & 10.14 & 10.04 & 9.85 & 9.87 & 9.85 & - & - & - & - & 10.15 \\
\hline Bank Swasta Nasional - Investasi & 10.02 & 9.98 & 9.81 & 9.57 & 9.43 & 9.42 & 9.28 & 9.2 & - & - & - & - & 9.59 \\
\hline Bank Swasta Nasional - Konsumsi & 11.1 & 11.06 & 11.01 & 10.91 & 10.86 & 10.83 & 10.78 & 10.77 & - & - & - & - & 10.92 \\
\hline Bank Asing dan Bank Campuran - Modal Kerja & 7.79 & 7.72 & 7.57 & 7.64 & 7.59 & 7.51 & 7.44 & 7.3 & - & - & - & - & 7.57 \\
\hline Bank Asing dan Bank Campuran - Investasi & 8.79 & 8.76 & 8.52 & 8.44 & 8.39 & 8.24 & 8.08 & 8 & - & - & - & - & 8.40 \\
\hline Bank Asing dan Bank Campuran - Konsumsi & 22.85 & 22.87 & 22.79 & 22.17 & 22.24 & 22.39 & 22.3 & 22.24 & - & - & - & - & 22.48 \\
\hline Bank Umum - Modal Kerja & 10.08 & 10.01 & 9.91 & 9.68 & 9.55 & 9.43 & 9.41 & 9.38 & - & - & - & - & 9.68 \\
\hline Bank Umum - Investasi & 9.87 & 9.83 & 9.7 & 9.45 & 9.32 & 9.3 & 9.21 & 9.16 & - & - & - & - & 9.48 \\
\hline Bank Umum - Konsumsi & 11.43 & 11.41 & 11.37 & 11.29 & 11.22 & 11.2 & 11.16 & 11.13 & - & - & - & - & 11.28 \\
\hline
\end{tabular}




\begin{tabular}{|c|c|c|c|c|c|c|c|c|c|c|c|c|c|}
\hline \multirow{3}{*}{ Kelompok Bank } & \multicolumn{13}{|c|}{ Suku Bunga Kredit Rupiah Menurut Kelompok Bank } \\
\hline & \multicolumn{13}{|l|}{2019} \\
\hline & Jan & Feb & Mar & Apr & May & Jun & Jul & Aug & Sep & Oct & Nov & Dec & Tahunan \\
\hline Bank Persero - Modal Kerja & 10.2 & 10.21 & 10.19 & 10.19 & 10.08 & 10.01 & 10.01 & 9.99 & 9.88 & 9.85 & 9.8 & 9.72 & 10.01 \\
\hline Bank Persero - Investasi & 10.13 & 10.11 & 10.11 & 10.07 & 10.04 & 10.03 & 10.02 & 9.96 & 9.91 & 9.88 & 9.83 & 9.75 & 9.99 \\
\hline Bank Persero - Konsumsi & 11.2 & 11.17 & 11.13 & 11.12 & 11.09 & 11.09 & 11.09 & 11.12 & 11.11 & 11.09 & 11.07 & 11.44 & 11.14 \\
\hline Bank Pemerintah Daerah - Modal Kerja & 11.19 & 11.23 & 11.12 & 11.15 & 11.23 & 11.23 & 11.29 & 11.27 & 11.27 & 11.24 & 11.14 & 10.8 & 11.18 \\
\hline Bank Pemerintah Daerah - Investasi & 11 & 10.99 & 11.06 & 11.1 & 11.07 & 11.05 & 10.94 & 11 & 10.91 & 11.15 & 11.09 & 11.04 & 11.03 \\
\hline Bank Pemerintah Daerah - Konsumsi & 12.19 & 12.15 & 12.04 & 12.06 & 12.01 & 11.98 & 11.95 & 11.91 & 11.86 & 11.83 & 11.8 & 11.75 & 11.96 \\
\hline Bank Swasta Nasional - Modal Kerja & 10.99 & 10.98 & 10.94 & 10.94 & 10.91 & 10.9 & 10.89 & 10.86 & 10.85 & 10.76 & 10.75 & 10.54 & 10.86 \\
\hline Bank Swasta Nasional - Investasi & 10.6 & 10.56 & 10.52 & 10.49 & 10.45 & 10.41 & 10.4 & 10.34 & 10.3 & 10.16 & 10.17 & 10.02 & 10.37 \\
\hline Bank Swasta Nasional - Konsumsi & 11.35 & 11.32 & 11.32 & 11.3 & 11.26 & 11.26 & 11.24 & 11.22 & 11.22 & 11.18 & 11.18 & 11.1 & 11.25 \\
\hline Bank Asing dan Bank Campuran - Modal Kerja & 9.07 & 9.07 & 9.03 & 8.96 & 8.84 & 8.8 & 8.67 & 8.57 & 8.27 & 8.16 & 8.05 & 7.83 & 8.61 \\
\hline Bank Asing dan Bank Campuran - Investasi & 9.94 & 9.97 & 9.85 & 9.81 & 9.77 & 9.75 & 9.57 & 9.44 & 9.23 & 9.16 & 9.04 & 8.83 & 9.53 \\
\hline Bank Asing dan Bank Campuran - Konsumsi & 24.3 & 24.23 & 24.07 & 23.94 & 23.33 & 23.3 & 23.34 & 23.2 & 23.24 & 23.21 & 23.32 & 22.91 & 23.53 \\
\hline Bank Umum - Modal Kerja & 10.52 & 10.55 & 10.51 & 10.5 & 10.43 & 10.39 & 10.39 & 10.36 & 10.29 & 10.22 & 10.2 & 10.03 & 10.37 \\
\hline Bank Umum - Investasi & 10.38 & 10.36 & 10.34 & 10.31 & 10.26 & 10.24 & 10.22 & 10.16 & 10.11 & 10.04 & 10.02 & 9.9 & 10.20 \\
\hline Bank Umum - Konsumsi & 11.72 & 11.68 & 11.64 & 11.62 & 11.57 & 11.57 & 11.55 & 11.55 & 11.53 & 11.51 & 11.49 & 11.62 & 11.59 \\
\hline
\end{tabular}

Suku bunga rata-rata tertimbang untuk kredit non prioritas.

Sumber: Bank Indonesia 2020

Secara umum rata rata suku bunga kredit perbankan di tahun 2020 lebih rendah dibendingkan di tahun 2019, hal ini disebabkan karena kasus pandemic korona mengakibatkan semakin tingginya permintaan akan hutang dikarenakan kebutuhan pendanaan yang sangat tinggi di dunia usaha untuk menutupi defisit keuangannya. Kita ketahui bahwa dengan naiknya suku bunga, maka beban bunga juga semakin meningkat. Dengan naiknya suku bunga akan menyebabkan perusahaan akan menurun permintaannya dalam peminjaman uang sehingga produksi juga menurun, sehingga bisa menyulitkan konsumen dalam mencari barang atau jasa. Hal ini sangat dijaga oleh pemerintah agar tidak terjadi permasalahan ekonomi yang semakin terpuruk saat ini.

\section{Kebijakan Makro Ekonomi Indonesia}

Setiap kebijakan ekonomi Indonesia saat ini bertujuan untuk mengatasi masalah-masalah ekonomi yang dihadapi. Berdasarkan kepada masalah-masalah makroekonomi yang dihadapi suatu Negara, tujuan-tujuan kebijakan makroekonomi adalah sebagai berikut :

a. Menstabilkan Kegiatan ekonomi

Kestabilan ekonomi merupakan hal yang diharapkan oleh setiap Negara pada umumnya, yang dapat diartikan sebagai kondisi dimana tidak terdapat pengangguran yang serius serta tingkat harga yang stabil. Dengan demikian pengertian kestabilan ekonomi meliputi perwujudan tiga hal berikut: (a) tingkat penggunaan tenaga kerja yang tinggi (b) tingkat harga-harga tidak menunjukkan perubahan yang berarti (c) terdapat keseimbangan diantara ekspor dan impor serta lalu lintas modal dari atau ke 
luar negeri. Tujuan kestabilan ekonomi berarti pula keinginan untuk menghindari fluktuasi yang tajam dalam Kegiatan ekonomi dari satu waktu ke waktu lainnya. Fluktuasi yang tidak dapat dikendalikan tidak akan menjamin terwujudnya tiga hal diatas.

b. Tingkat penggunaan tenaga kerja (kesempatan) penuh tanpa inflasi

Setiap Negara akan selalu berusaha untuk mencapai tingkat penggunaan tenaga kerja penuh tanpa inflasi merupakan yang paling ideal dari tujuan-tujuan lainnya. Apabila suatu masyarakat dapat selalu mencapai tujuan ini, dengan sendirinya tujuan-tujuan lainnya yaitu mencapai kestabilan ekonomi dan pertumbuhan ekonomi yang teguh akan tercapai. Pada umumnya berbagai Negara tidak dapat terus menerus mencapai penggunaan tenaga kerja penuh, factor yang menyebabkan adalah kekurangan pengeluaran agregat.

c. Menghindari Inflasi

Inflasi dapat berakibat buruk atas kesejahteraan serta kemakmuran masyarakat dan akan mengganggu Kegiatan perekonomian. Adakalanya inflasi sebagai akibat dari ketidakstabilan politik dan ekonomi suatu Negara. Dalam keadaan seperti ini biasanya tingkat inflasi tinggi dan sukar dikendalikan. Tetapi seringkali inflasi timbul sebagai akibat permintaan masyarakat yang berlebihan atau kenaikan dalam biaya produksi. Kebijakan pemerintah diperlukan untuk mengatasi masalah inflasi seperti itu.

d. Mewujudkan pertumbuhan ekonomi yang teguh

Tujuan ini merupakan tujuan makroekonomi jangka panjang. Dari satu periode ke periode lainnya factor-faktor produksi mengalami pertambahan kuantitas dan kualitasnya. Pertambahan penduduk pada akhirnya akan menambah keterampilan dan kemampuan tenaga kerja. Penawaran modal menambah barang-barang modal dan meningkatkan penggunaan teknologi yang lebih modern. Setidaknya ada dua alasan yang menyebabkan suatu Negara harus berusaha mencapai pertumbuhan ekonomi yang teguh dalam jangka panjang: untuk menyediakan kesempatan kerja kepada tenaga kerja yang terus menerus bertambah dan untuk menaikkan tingkat 
kemakmuran masyarakat. Kedua alasan ini merupakan pendorong utama kepada pemerintah untuk berusaha menciptakan pertumbuhan ekonomi yang teguh.

e. Mewujudkan kekukuhan neraca pembayaran dan kurs valuta asing

Tujuan kebijakan makroekonomi terakhir adalah untuk mewujudkan kekukuhan neraca pembayaran dan kurs valuta asing. Kekukuhan neraca pembayaran diperlihatkan dari surplus neraca pembayaran. Selain itu nilai mata uang domestic yang kukuh dibandingkan nilai mata uang asing, akan meningkatkan daya saing perekonomian suatu Negara.

\section{Betuk-Bentuk Kebijakan Makro Ekonomi}

Bentuk-bentuk Kebijakan Makro ekonomi yang dilakukan pemerintah Republik Indonesia saat ini yaitu :

a. Kebijakan fiskal, meliputi langkah-langkah pemerintah membuat perubahan dalam bidang perpajakan dan pengeluaran pemerintah dengan maksud untuk mempengaruhi pengeluaran agregat dalam perekonomian. Menurut pandangan Keynes, kebijakan fiskal adalah sangat penting untuk mengatasi pengangguran yang relative serius. Melalui kebijakan fiskal pengeluaran agregat dapat ditambah dan langkah ini akan menaikkan pendapatan nasional dan tingkat penggunaan tenaga kerja.

b. Kebijakan moneter, meliputi langkah-langkah pemerintah yang dilaksanakan oleh bank sentral untuk mempengaruhi penawaran uang dalam perekonomian atau merubah tingkat suku bunga dengan maksud untuk mempengaruhi pengeluaran agregat.

c. Kebijakan segi penawaran, bertujuan untuk mempertinggi efesiensi Kegiatan perusahaan-perusahaan sehingga dapat menawarkan barang-barangnya dengan harga yang lebih murah atau dengan mutu yang lebih baik. Salah satu kebijakan segi penawaran adalah kebijakan pendapatan (income policies) langkah pemerintah yang bertujuan mengendalikan tuntutan kenaikan pendapatan pekerja. Pemerintah akan melarang tuntutan kenaikan upah yang melebihi kenaikan produktivitas pekerja, sehingga akan menghindari kenaikan biaya produksi yang berlebihan. Kebijakan segi penawaran lebih menekankan kepada (a) meningkatkan kegairahan tenaga kerja untuk 
bekerja dan (b) meningkatkan usaha para pengusaha untuk mempertinggi efesiensi Kegiatan memproduksinya.

\section{PENUTUP}

\section{Kesimpulan}

Mikroekonomi adalah studi tentang bagaimana rumah tangga dan perusahaan mengambil keputusan dan bagaimana para pengambil keputuusan ini berinteraksi di pasar. Prinsip utama mikroekonomi adalah bahwa rumah tangga dan perusahaan berusaha mencapai optimalisasi.Sementara makroekonomi, cabang utama dari ekonomi menangani kepada isu-isu yang bersifat makro atau lebih luas lagi.termasuk didalamnya mengenai jumlah agregat ekonomi, seperti tingkat dan laju pertumbuhan produksi nasional, suku bunga, pengangguran dan inflasi.

Permasalahan utama dalam perekonomian yang selalu dihadapi oleh setiap negara. permasalahan tersebut adalah sebagai berikut: (1) Masalah pertumbuhan ekonomi (2) Masalah ketidakstabilan ekonomi (3) Masalah pengangguran (4) Masalah Kenaikan Harga-harga (Inflasi) (5) Masalah Neraca Perdagangan dan Neraca Pembayaran.

Adapun tujuan dari kebijakan ekonomi makro adalah: Menstabilkan Kegiatan ekonomi, tingkat penggunaan tenaga kerja (kesempatan) penuh tanpa inflasi, Menghindari Inflasi, Mewujudkan pertumbuhan ekonomi yang teguh, Mewujudkan kekukuhan neraca pembayaran dan kurs valuta asing, untuk mewujudkan kekukuhan neraca pembayaran dan kurs valuta asing. Bentuk-bentuk dalam Kebijakan Makro ekonomi meliputi: Kebijakan fiskal,Kebijakan moneter, Kebijakan segi penawaran.

\section{Saran}

Saran untuk penelitian berikutnya bahwa terkait dengan masalah pembahasan penelitian ini perlu dikembangkan terutama tentang metode grafik dan metode simpleks pada kondisi dengan penambahan masalah yang lebih kompleks sehingga menambah pengetahuan dan memperkuat analasia terhadap pemanfaatan dan penggunaan metode ini untuk meningkatkan tingkat keuntungan dari sebuah pabrik. 


\section{DAFTAR PUSTAKA}

Adiwarman A Karim, Ekonomi Makro Islami, Jakarta: Rajawali Press, 2008.

https://citrawulani.wordpress.com/mata-pelajaran/ekonomi/pengertian-ekonomi-secara-umu

$\underline{\mathrm{m} /}$

https://www.bps.go.id/

Huda,Nurul.Ekonomi Makro Islam, Jakarta: Kencana, 2008.

Iskandar Putong, Economics Pengantar mikro dan Makro, (Jakarta,Mitra WacanaMedia, 2010

Karl E Case dan RayC Fair, Prinsip-prinsip Ekonomi Mikro, Penerjemah Benyamin Molan, Jakarta: Pearso Education Asia, 2002.

M Rianto, Nur.Teori Makro Ekonomi Islam konsep, teori dan analisis, Bandung: Alfabeta, 2010.

Nasution, Mustafa Edwin. Pengenalan Eksklusif Ekonomi Islam, Jakarta:Kencana Prenada Media Group,2006

Sukirno,Sadono.Pengantar Makroekonomi Ed.2,Jakarta: Rajawali Press, 1998

Waluyo, Dwi Eko. Ekonomika Makro Edisi Revisi, UMM PRESS, 2007.

www.mediaindonesia.com 